\title{
BLOOD GROUP ANTIBODY TITRES IN HOMOSPECIFIC AND HETEROSPECIFIC PREGNANCIES
}

\author{
R. TOAFF, DANIEL AYALON* AND DAVID NELKEN $\dagger$ \\ 10 Hermann Cohen Street, Tel Aviv, Israel, \\ * Department of Obstetrics and Gynáecology A, Tel Aviv University Medical School, \\ Municipal Medical Centre, Tel Aviv-Yaffo, Tel Aviv, Israel, and \\ $\uparrow$ Department of Clinical Microbiology, Hebrew University-Hadassah Medical School, \\ Jerusalem, Israel
}

(Received 24th January 1966)

Summary. Blood group antibody titre rises in the same way in both heterospecific and homospecific pregnancies of previously immunized mothers. Titre rises of $\mathrm{AB}$ antibodies were observed very early in pregnancy. The nature of the antigenic stimulus for production of these antibodies remains obscure. The relationship between chorionic gonadotrophin and blood group antibody levels is discussed.

\section{INTRODUGTION}

It has long been known that the blood group antibody titre may rise considerably during pregnancy. This occurrence is found frequently, though not exclusively, in heterospecific pregnancies.

While in heterospecific pregnancies an early rise of antibody titres may be assumed to indicate the passage through the placenta of the specific soluble group substance secreted by the foetus, a marked rise during the puerperium suggests that the group substance reaches the mother chiefly during labour, possibly through the infusion of foetal blood into the maternal circulation (Zipursky, Pollock, Neelands, Chown \& Israels, 1963).

The same explanation cannot apply to the antibody titre rise in homospecific pregnancies, both during and after delivery; an anamnestic phenomenon, therefore, caused by stimulation of maternal antibody production by other foetal antigens, has been postulated (Robinson, Dunn \& Wong, 1960).

No attempt, however, was made to suggest a relationship between antibody titre and specific hormonal changes of pregnancy in order to explain the peculiarity of antibody behaviour in pregnancy. The first hint of a possible relationship between chorionic gonadotrophin ( $\mathrm{HCG}$ ) and immune group antibodies (haemolysins) appeared in a study by Wren \& Vos (1961) on blood group incompatibility as a cause of spontaneous abortion.

In view of the possible significance of this theory, we reviewed the material which has been collected in the Department of Obstetrics and Gynaecology A of the Tel Aviv Municipal Medical Centre in the course of a study on ABO incompatibility as affecting fertility, for observations having a bearing on this particular aspect of the problem. 


\section{MATERIALS AND METHODS}

Titrations of anti-A and anti-B antibodies were performed by the double serial dilution method, in $0.2 \mathrm{ml}$ quantities. One drop of a $5 \%$ suspension of three times washed erythrocytes was added to each tube.

For the determination of the so-called 'complete' or saline agglutinins, the sera were diluted with a $0.85 \% \mathrm{NaCl}$ solution. The 'incomplete' or immune antibodies were determined by two methods: dilution of the sera in a $6 \%$ dextran (intrinsic viscosity $0.40 / 20^{\circ} \mathrm{C}$ ) solution, and by using papain-treated erythrocytes of the donor used in the other method. No marked differences were ever encountered between the results of the two methods.

Results were determined macroscopically after centrifugation of the tubes at $1000 \mathrm{rev} / \mathrm{min}$ for $15 \mathrm{sec}$. The last tube showing macroscopic agglutination was taken as the titre.

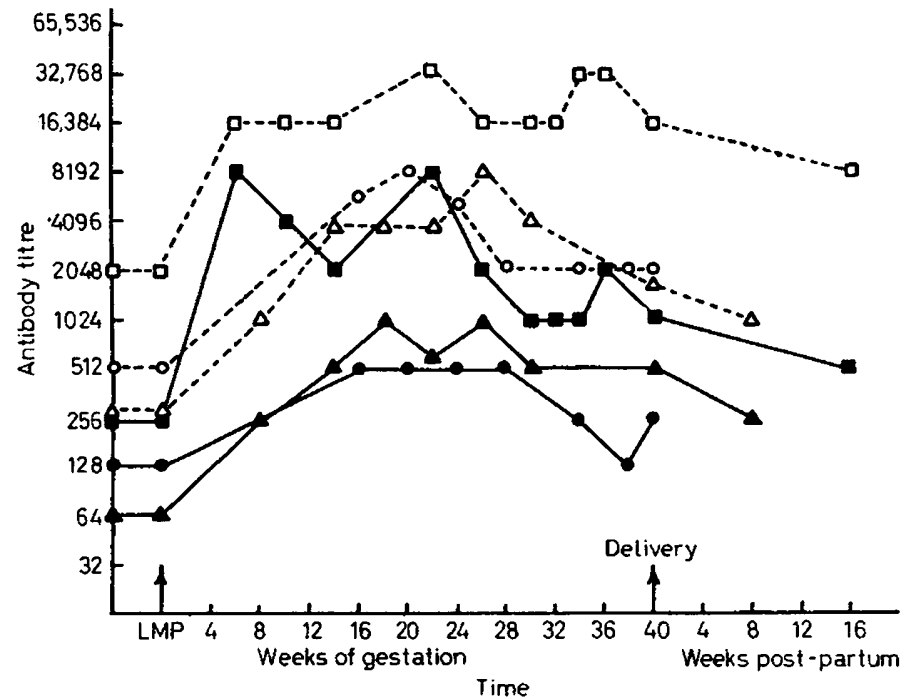

TEXT-FIG. 1. Variations in antibody titres throughout three heterospecific pregnancies of previously immunized mothers. Curves 1 ( $\square$ ) and $1 \mathrm{a}(\square)$ : Complete and incomplete anti-A antibody titres in Case 1 . Curves $2(0)$ and $2 \mathrm{a}(\mathrm{O})$ : Complete and incomplete anti-A antibody titres in Case 2 . Curves $3(\Delta)$ and $3 a(\Delta)$ : Complete and incomplete anti-B antibody titres in Case 3.

A group of cases selected for study of the antibody titre throughout pregnancy had, in the past, exhibited repeated abortions or pregnancies ending in birth of babies affected by haemolytic disease due to iso-immunization. In these previously immunized mothers a further pregnancy produced as a rule a marked and early rise of the antibody titre.

\section{OBSERVATIONS}

In previously immunized mothers the curve of anti-A or anti-B antibody titre shows a marked rise in a subsequent pregnancy regardless of whether this pregnancy is heterospecific or homospecific

The curves plotted in Text-fig. 1 show the variations in antibody titres throughout three heterospecific pregnancies. Curves $1,1 \mathrm{a}, 2$ and $2 \mathrm{a}$ refer to two ORh + women who had been previously immunized by A pregnancies 
and curves $3,3 \mathrm{a}$, refer to an $\mathrm{ARh}+$ woman who had been previously immunized by $B$ pregnancies.

Case 1 (curves 1, 1a). L.J., 31 years old, married 6 years, blood group $\mathrm{ORh}+$. At the age of 15, while an inmate of a German concentration camp, she had, apparently for purposes of experimentation, several blood transfusions which were followed by typical haemolytic reaction. Her husband is $A_{1} R h+$. The patient had previously had five pregnancies:

(1) 1958: normal delivery. The baby, $3350 \mathrm{~g}, \mathrm{~A}_{1} \mathrm{Rh}+$, suffered from severe jaundice, which required exchange transfusion, and recovered.

(2) 1960: Premature delivery at the 6th month. The newborn died immediately.

(3) 1960: Spontaneous abortion at the 3rd month.

(4) 1961: Missed abortion at the 4th/2nd month.

(5) 1961: Premature delivery at the 7th month. The baby, $1400 \mathrm{~g}$, died $15 \mathrm{hr}$ after delivery. His blood group was $\mathrm{A}_{1} \mathrm{Rh}+$.

One day after the last premature delivery the antibody titre was: anti-A complete $1: 512$, incomplete $1: 4096$; anti-B complete $1: 128$, incomplete $1: 512$. After 2 months: anti-A complete $1: 256$, incomplete $1: 2048$.

Four months after her last delivery the patient became pregnant again. Following suture of the cervix for incompetent internal os, the pregnancy had an uneventful course. The baby weighed $3500 \mathrm{~g}$ and was $\mathrm{A}_{1} \mathrm{Rh}+$. He suffered from haemolytic disease, which required exchange transfusion, but eventually recovered.

Case 2 (curves 2, 2a). C.A., 29 years old, married 8 years, blood group $\mathrm{ORh}+$. Her husband is $\mathrm{A}_{1} \mathrm{Rh}+$ and a secretor. The patient had three previous pregnancies:

(1) 1954: term delivery of a boy, $3450 \mathrm{~g}, \mathrm{~A}_{1} \mathrm{Rh}+$.

(2) 1957: term delivery. The baby, $\mathrm{A}_{1} \mathrm{Rh}+$, did not become jaundiced.

(3) 1962: missed abortion at the 5th/3rd month.

Following the missed abortion, antibody titrations were done. After 1 day: anti-A complete $1: 256$, incomplete $1: 4.096$; anti-B complete $1: 64$, incomplete $1: 256$. Six weeks later: anti-A complete $1: 128$, incomplete $1: 512$.

The patient conceived again 8 months after her last pregnancy and delivered at term a living and healthy baby, whose blood group was $A_{1} R h+$.

Case 3 (curves 3, 3a). E.Y., 28 years old, married 12 years, blood group $A_{1} R h+$. Her husband has blood group $B R h+$ and is a secretor. The patient had five previous pregnancies:

(1) 1952: missed abortion 4th month.

(2) 1953: missed abortion 6th/4th month.

(3) 1954: missed abortion 6th/4th month.

(4) 1955: premature stillbirth. The foetus, $1000 \mathrm{~g}$, had multiple malformations.

(5) 1959: missed abortion 5th/3rd month. 
The patient became pregnant again in 1962. Following antibiotic treatment and suture of the cervix because of incompetent internal os, both pregnancy and delivery were uneventful. The baby, $3190 \mathrm{~g}, \mathrm{~A}_{1} \mathrm{BRh}+$, was healthy.

During the 6 th pregnancy repeated titrations were done as from the 4 th month. The anti-B complete antibody titre rose from $1: 64$ to $1: 512$ at the 8th month, while the incomplete antibody titre rose from $1: 256$ to $1: 8192$, remaining in the same level up to delivery. The complete antibody titre, a month after delivery, was $1: 256$, the incomplete antibody titre was $1: 2048$.

Ten months after delivery the patient became pregnant. She again received antibiotic treatment and a Shirodkar-type procedure and delivered at term a normal baby, $3100 \mathrm{~g}$, blood group $\mathrm{A}_{1} \mathrm{BRh}+$, which remained healthy.

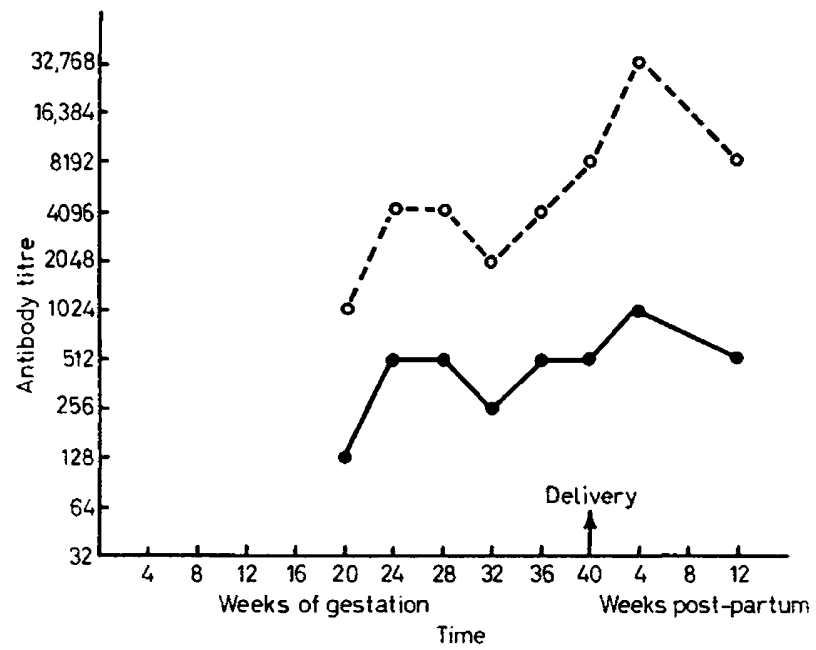

TEXT-FIG. 2. Variations in complete (๑) and incomplete (O) anti-A antibody titres in a Group $O$ woman, previously immunized by $A$ pregnancies, in the course of a subsequent homospecific pregnancy (Case 4).

The rise in complete and incomplete antibody titres in two $\mathrm{ORh}+$ mothers, married of $\mathrm{ARh}+$ husbands, was studied during a further pregnancy which eventually was found to be homospecific. Both mothers had previously given birth to babies affected by haemolytic disease due to $\mathrm{ABO}$ iso-immunization (Text-figs. 2 and 3 ).

Case 4 (Text-fig. 2). S.R., 25 years old, married 7 years, blood group ORh+. Her husband has blood group $A_{1} R h+$. The patient had four previous pregnancies:

(1) 1956: spontaneous abortion at the 3rd month.

(2) 1957: spontaneous abortion at the 4th month.

(3) 1959: premature delivery at the 8th month. The newborn, $2200 \mathrm{~g}$, blood group $A_{1} R h+$, was affected by haemolytic disease and died in its 5 th day in spite of exchange transfusion. 
(4) 1961: a girl, $3000 \mathrm{~g}$, blood group $\mathrm{A}_{1} \mathrm{Rh}+$, was delivered at term. Because of haemolytic disease due to $A B O$ iso-immunization, she had an exchange transfusion and recovered.

Throughout the 5th pregnancy, which started 1 year later, serial titrations of anti-A complete and incomplete antibodies were done. Both rose to very high titres during pregnancy, with a peak after delivery. The baby delivered at term, a female, $2970 \mathrm{~g}$, was healthy. Her blood group was $\mathrm{ORh}+$.

Case 5 (Text-fig. 3). R.A., 19 years old, married 5 years, blood group $\mathrm{ORh}-$. Her husband has blood group $\mathrm{A}_{1} \mathrm{Rh}-$.

The patient had only one previous pregnancy in 1960. She gave birth at term to a boy, $3550 \mathrm{~g}$, blood group $\mathrm{A}_{1} \mathrm{Rh}$-, who developed haemolytic disease, due to $\mathrm{ABO}$ iso-immunization. He did not require an exchange transfusion,

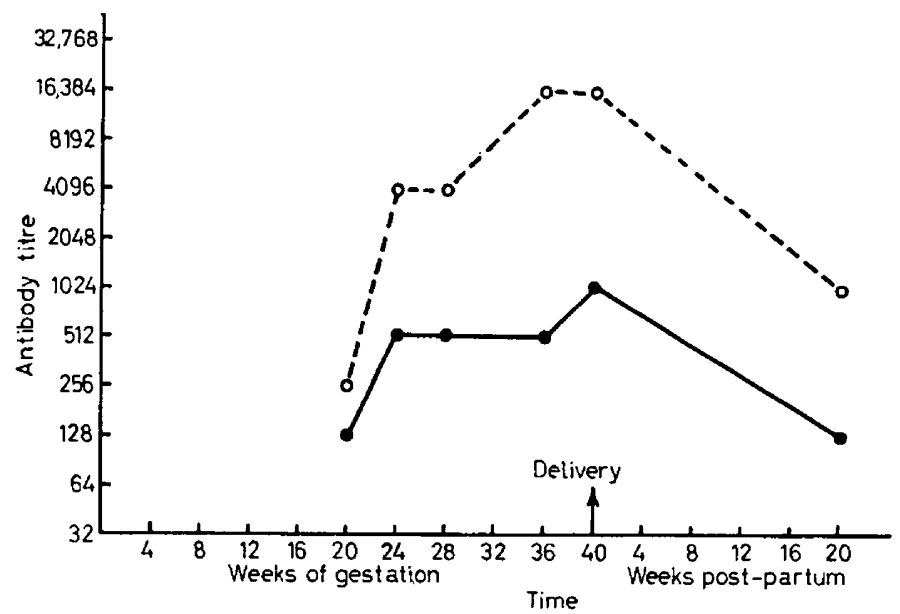

TEXT-FIG. 3. Variations in complete $(\bullet)$ and incomplete $(O)$ anti-A antibody titres in a Group $\mathrm{O}$ woman, previously immunized by an $\mathrm{A}$ pregnancy, in the course of a subsequent homospecific pregnancy (Case 5 ).

but suffered from anaemia of 3 million erythrocytes and $8 \mathrm{~g}$ haemoglobin for several months.

Two years later the patient became pregnant again and the anti-A and the anti-B complete and incomplete antibody titres were examined serially throughout pregnancy. Very high titres were observed. The boy delivered at term, $3750 \mathrm{~g}$, perfectly healthy, was found to be ORh - .

In previously immunized women the rise in antibody titre occurs in very early stages of further pregnancies

Text-fig. 4 and Table 1 show the results obtained by antibody titration in five previously immunized women shortly after they missed a menstrual period, $2 \frac{1}{2}$ to 6 weeks after conception. A very significant rise in the incomplete antibody titre was observed, even 18 days after conception. 


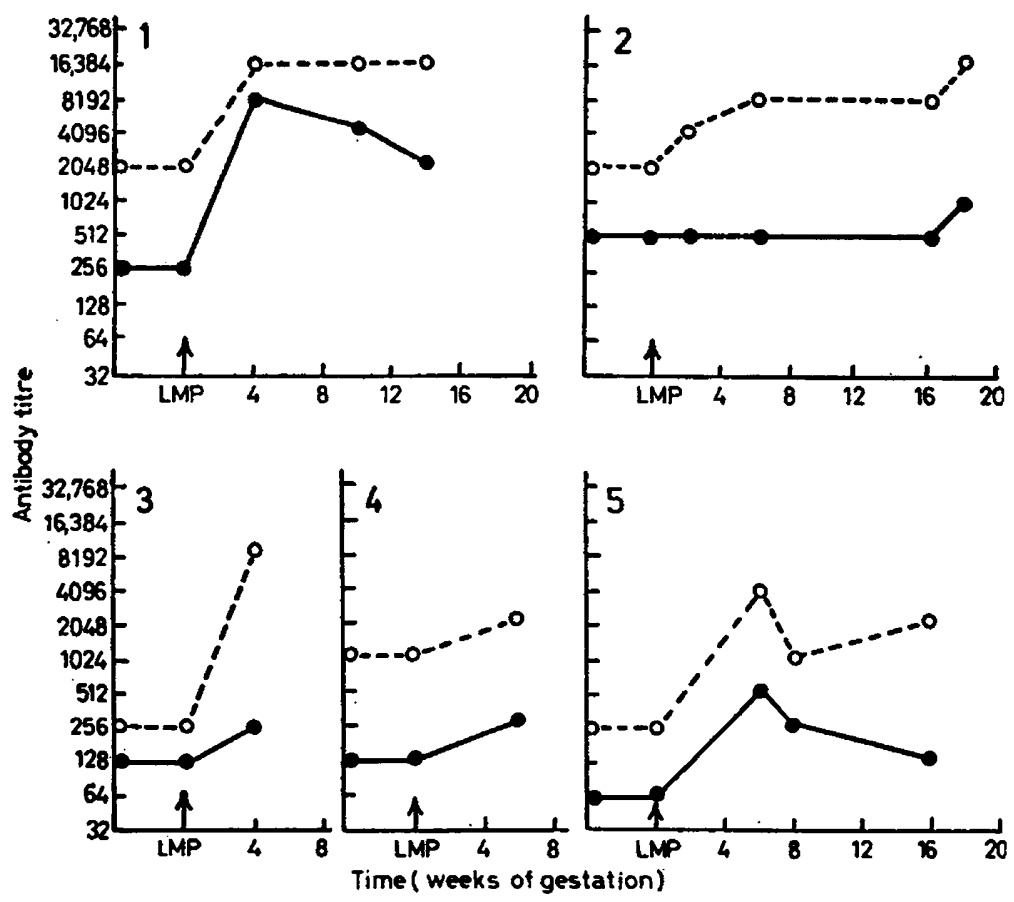

TEXT-FIG. 4. Early rise of group antibody titres in five pregnancies (see relative data in Table 1). Complete; 0 , incomplete.

\section{TABLE 1}

RISE IN ANTIBODY TITRE IN EARLY STAGES OF PREGNANGY IN PREVIOUSLY IMMUNIZED WOMEN

\begin{tabular}{|c|c|c|c|c|c|c|c|c|c|}
\hline \multirow{3}{*}{$\begin{array}{l}\text { Serial } \\
\text { No. }\end{array}$} & \multirow{3}{*}{ Name } & \multirow{3}{*}{$\begin{array}{l}\text { Blood } \\
\text { group } \\
\text { of } \\
\text { mother }\end{array}$} & \multirow{3}{*}{$\begin{array}{c}\text { Antibody } \\
\text { tested }\end{array}$} & \multicolumn{2}{|c|}{$\begin{array}{c}\text { Antibody titre } \\
\text { before pregnancy }\end{array}$} & \multicolumn{4}{|c|}{ Antibody titre in early pregnancy } \\
\hline & & & & \multirow{2}{*}{ Complete } & \multirow{2}{*}{ Incomplete } & \multicolumn{2}{|c|}{ Days after } & \multicolumn{2}{|c|}{ Titre } \\
\hline & & & & & & l.m.p. & Concept. & Complete & Incomplete \\
\hline $\begin{array}{l}1 \\
2 \\
3 \\
4 \\
5\end{array}$ & $\begin{array}{l}\text { L.J. } \\
\text { S.S. } \\
\text { B.S. } \\
\text { L.B. } \\
\text { F.R. }\end{array}$ & $\begin{array}{l}\text { ORh+ } \\
\text { ORh+ } \\
\text { ORh+ } \\
A_{1} R h+ \\
A_{1} R h+\end{array}$ & $\begin{array}{l}\text { Anti-A } \\
\text { Anti-A } \\
\text { Anti-A } \\
\text { Anti-B } \\
\text { Anti-B }\end{array}$ & $\begin{array}{l}1: 256 \\
1: 512 \\
1: 128 \\
1: 128 \\
1: 64\end{array}$ & $\begin{array}{l}1: 2048 \\
1: 2048 \\
1: 1024 \\
1: 256 \\
1: 256\end{array}$ & $\begin{array}{l}32 \\
49 \\
56 \\
38 \\
44\end{array}$ & $\begin{array}{l}18 \\
35 \\
41 \\
24 \\
30\end{array}$ & $\begin{array}{l}1: 8192 \\
1: 512 \\
1: 256 \\
1: 256 \\
1: 512\end{array}$ & $\begin{array}{l}1: 16384 \\
1: 8192 \\
1: 2048 \\
1: 8192 \\
1: 4096\end{array}$ \\
\hline
\end{tabular}

No. 1: See case history of Case 1.

No. 2: Aged 30, married 7 years. Husband $A_{1} R h+$. In the past two normal deliveries followed by an early abortion, an artificial abortion and a missed abortion.

No. 3: Aged 21, married 6 months. In the past, a single missed abortion, 4 months previously.

No. 4: Aged 27, married 3 years. Husband BRh + . In the past an early abortion, two normal deliveries and a premature stillbirth.

No. 5: Aged 31, married 3 years. Husband BRh+. In the past a caesarean delivery, followed by a missed abortion. 


\section{DISCUSSION}

Smith (1945) found an antibody titre rise in forty out of forty-six heterospecific pregnancies. Boorman, Dodd \& Morgan (1945) detected a rise in relevant maternal saline-agglutinin titre in thirty-six out of forty-four cases of heterospecific pregnancies; they noted that the titre increased from 4 to over 64 times and that the peak was usually reached between the 10th and the 20th day of puerperium. Robinson, Dunn \& Wong (1960) found a significant rise in saline anti-A and anti-B agglutinin titre at some stage of heterospecific pregnancy in twenty out of forty-seven women, the maximum rise occurring more than 1 week after delivery. They observed, moreover, that the bulk of the rise tended to occur in the puerperium, but a slight upward trend was often noted on repeated pre-natal testing.

As to homospecific pregnancies, most authors have found no rise in maternal saline-agglutinin titre. Yet Robinson et al. (1960) could detect a general slight tendency for the titre of anti-A and anti-B antibodies in saline to rise after birth even in homospecific cases.

As to the agglutinin titre in albumin at $37^{\circ} \mathrm{C}$, these same authors found it increased in eleven out of fifty-four heterospecific pregnancies and in six out of thirty-six homospecific pregnancies. Jouvenceaux (1950) described a homospecific pregnancy in which an immune anti-A antibody even increased in titre during pregnancy.

As to group haemolysins, Jonsson (1935) first showed on a large scale that these antibodies tended to appear in maternal sera as a result of heterospecific pregnancy. Robinson et al. (1960) found a slight increase of anti-A haemolysin activity even in some cases of homospecific pregnancy and a marked increase in heterospecific pregnancies, so that all of twenty-three maternal sera in the latter group were eventually positive for anti-A haemolysin in the post-partum period.

In our material, in two mothers already immunized by previous heterospecific pregnancies, the rise in antibody titre observed in a subsequent homospecific pregnancy followed the same pattern as in heterospecific pregnancies. This observation seems to prove that, following immunization, pregnancy acts as a non-specific stimulus to further antibody production, a stimulus not identical with the $\mathrm{AB}$ antigen.

Beside this we observed in five cases that the rise in antibody titre and particularly in immune-antibody titre started very early in pregnancy. We found it very evident at a stage of pregnancy when, to the best of our knowledge, the foetus does not produce the group substance. Szulman (1964) could demonstrate $A, B$ and $H$ substances in the cell wall of endothelium and epithelium of the $5 \frac{1}{2}$ - to 7-week-old embryo, dated from the day of ovulation, while soluble substances appeared 2 weeks later. Our observations of early rise in immune antibodies seems to be a further proof that the rise in antibody titre, occurring in previously immunized pregnant women, is not due to $A B$ antigens.

Speculation on the nature of this unknown stimulus could suggest a direct relationship to the typical hormone of pregnancy, the chorionic gonadotrophin. This hypothesis would offer an explanation of several features of the antibody behaviour observed by us. The curve of antibody rise, for instance, in both 
heterospecific and homospecific pregnancies of previously immunized women, is roughly superimposable on the curve of HGG urinary excretion throughout pregnancy. Both curves show a very early rise. While the HCG curve shows a peak in the 3rd month, the antibody curve has a later peak, which could possibly be explained by the relative slowness of the immune reaction. But in no case could the HCG stimulation theory explain the frequent rise in antibody titre in early puerperium, as in the latest stages of pregnancy the HCG excretion is at its lowest ebb. No direct link between levels of HCG and immune antibody titre can therefore be postulated.

In in-vitro experiments Wren \& Voss (1961) found that preparations of HCG are capable of inhibiting the haemolytic potentialities of haemolysins for the A and B group factors. This finding suggested to them a mechanism whereby HCG neutralizes the haemolysins produced by group immunization and so prevents the abortion which would be liable to occur by red cell haemolysis or by tissue destruction. To investigate their theory they examined fifty-six women who were known habitual aborters. When these women conceived again the level of HCG and the presence of haemolysins were tested weekly. In the majority of cases when the HCG level was high, no haemolysins were detected; in those cases where the HGG level fell, haemolysins became apparent and remained so till either an abortion occurred or the HGG level rose once again. Exact data of their observations have not been published.

Those in-vitro experiments which were interpreted as a proof that preparations of HCG inhibit haemolysins for the A and B group factors, are better explained by the fact already known through the observations of Freda, Wiener \& Gordon (1957) and Tortora (1959) that commercial preparations obtained from pooled human urine contain, beside the active hormone, A and B blood group substances. The neutralization of the haemolysins for the A and B substances should not be assumed, therefore, to be an expression of HCG and haemolysins interaction, but of a simple antigen-antibody reaction. As to the in-vivo experiments on the repeated aborters, in which a direct correlation was sought between the falling levels of HCG and presence of haemolysins, it seems to us that these two parameters are only indirectly related. The plasma level and urinary excretion of HCG reflect the functional state of the placenta, and fall, therefore, in disturbed pregnancy or abortion independently of the cause which deranged its function. On the other hand, the appearance of immune antibodies and their titre are related only to the presence and the intensity of the immunization and possibly to the break-down of the defence mechanism of the maternal organism against foetal antigens. The appearance of antibodies and rise of their titre is to be expected, therefore, when pregnancy dies and especially if the nonfunctioning placenta is retained in the womb, while, at the same time, the HCG level will drop rapidly. These effects are independent one of the other but both of them are linked to the placental death.

\section{REFERENCES}

Boorman, K. E., Dodd, B. E. \& Morgan, W. I. J. (1945) Enhancement of the action of immune haemagglutinins by human serum. Nature, Lond. 155, 663.

FredA, V. J., Wiener, A. S. \& Gordon, E. B. (1957) An unsuspected source of A-B-O sensitization. Am. F. Obstet. Gynec. 73, 1148. 
Jonsson, B. (1935) Zur Frage der heterospezifichen Schwangerschaft. Acta path. microbiol. scand. 13, 424.

JOUVENCEAUX, A. (1950) L'isoimmunisation maternelle aux agglutinogens $A$ et $B$ et ses rapports avec les maladies hemolytiques du nouveau né. Thèse de Lyon (cited by Robinson et al.).

Robinson, G. C., Dunn, H. G. \& Wong, L. C. (1960) Observations on ABO incompatibility between mother and infant. Acta paediat., Stockh. 48, Suppl. 120.

SмITH, G. H. (1945) Iso-agglutinin titres in heterospecific pregnancy. F. Path. Bact. 57, 113.

Szulman, A. E. (1964) The blood group antigens A, B and $\mathbf{H}$ in tissues of human embryos. Bibl. Haemat. 19, 575.

ToRToRA, M. (1959) Immunization from chorionic gonadotropin. Int. 7. Fert. 41, 230.

WREN, B. G. \& Vos, G. H. (1961) Blood group incompatibility as a cause of spontaneous abortion. $\mathcal{J}$. Obstet. Gynaec. Br. Commonw. 68, 637.

Zrpursky, A., Pollogk, J., Neelands, P., Ghown, B. \& Israels, L. G. (1963) The transplacental passage of foetal red blood-cells and the pathogenesis of $\mathrm{Rh}$ immunization during pregnancy. Lancet, ii, 489. 